\title{
Schumpeter and the end of Western Capitalism
}

\section{William Kingston}

\section{Journal of Evolutionary Economics}

ISSN 0936-9937

Volume 24

Number 3

J Evol Econ (2014) 24:449-477

DOI 10.1007/s00191-013-0312-x

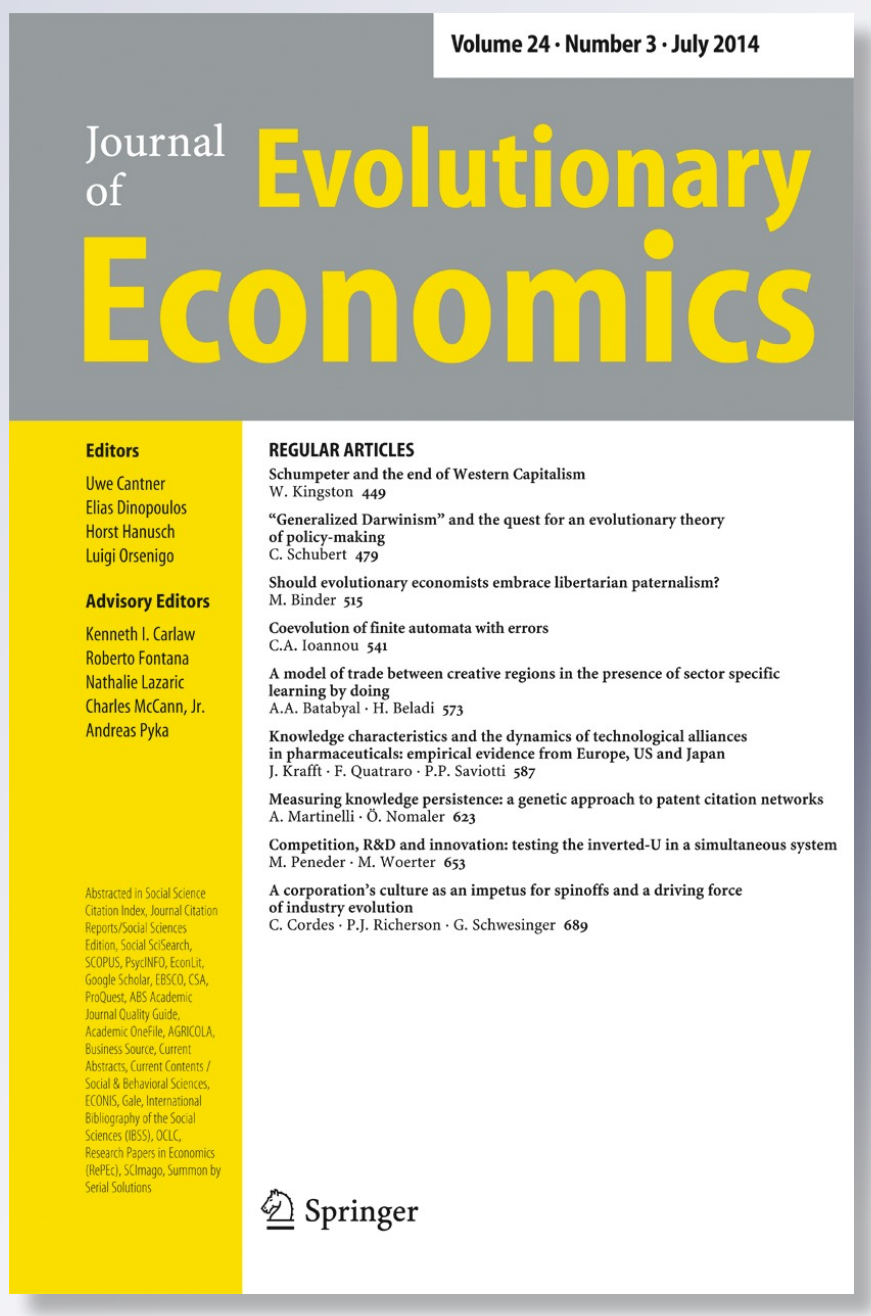

Springer 
Your article is protected by copyright and all rights are held exclusively by SpringerVerlag Berlin Heidelberg. This e-offprint is for personal use only and shall not be selfarchived in electronic repositories. If you wish to self-archive your article, please use the accepted manuscript version for posting on your own website. You may further deposit the accepted manuscript version in any repository, provided it is only made publicly available 12 months after official publication or later and provided acknowledgement is given to the original source of publication and a link is inserted to the published article on Springer's website. The link must be accompanied by the following text: "The final publication is available at link.springer.com". 


\title{
Schumpeter and the end of Western Capitalism
}

\section{William Kingston}

Published online: 25 April 2013

(C) Springer-Verlag Berlin Heidelberg 2013

\begin{abstract}
Schumpeter's forecast in his Capitalism, Socialism and Democracy (1942) that 'a socialist form of society will inevitably emerge from an equally inevitable decomposition of capitalist society' did great damage to his reputation. This was especially so after the fall of the Berlin wall, when the spectre of Communism seemed to have been finally exorcised. The current financial crisis, however, has vindicated him. For Schumpeter, capitalism rightly meant, not just individual property rights, but the ability to 'create money from nothing.' This is such an enormous and dangerous power that it obviously has to be subject to the strictest constraint, which was traditionally provided, however imperfectly, by denial of incorporation with limited liability to those who dealt in money. The decline of capitalism began when financiers were released from this discipline, and it ended with the catastrophe caused by belief that bureaucratic control could replace it. The cause of the change was the progressive capture of democratically elected politicians by interests. On this, Schumpeter's The Crisis of the Tax State (1918) was almost as insightful as his later book. When Governments could not allow banks to fail, they signalled the definitive arrival of centralized financing, which is a fundamental characteristic of a socialist economy.
\end{abstract}

Keywords Capitalism $\cdot$ Schumpeter $\cdot$ Socialism

JEL Classifications A13 - B15 - K20 - P7 · P20

W. Kingston $(\square)$

Trinity College, Dublin, Ireland

e-mail: wkngston@tcd.ie 


\section{Introduction}

In the book which Schumpeter thought the least important of his writings, but which remains his best known, Capitalism, Socialism and Democracy, he claimed that by 'extrapolating observable tendencies,' capitalism would eventually produce an 'atmosphere of almost universal hostility to its own social order' (Schumpeter [1942] 1997, 143). Consequently, 'a socialist form of society will inevitably emerge from an equally inevitable decomposition of capitalist society' ... 'there is inherent in the capitalist system a tendency towards self-destruction...[it] not only destroys its own institutional framework but it also creates the conditions for another' (ibid. 162). He was of course writing about the Western world, since at the time the way in which forms of capitalism would be enthusiastically embraced in the Far East could not have been imagined.

This forecast damaged Schumpeter's reputation, especially during the years after the fall of the Berlin wall, when the spectre of Communism appeared to have been finally exorcised, and neoclassical economics was hardly questioned. A symposium which was published to revisit his book after 50 years (Diamond and Plattner 1993) contains phrases such as 'almost every one of its main propositions has been empirically falsified' (Berger); 'erred in his predictions' (Bhagwati); 'remarkable inversions of his expectations' (Fukuyama); and 'wrong about the political failure of capitalism' (Lipset). Since then, however, events have vindicated Schumpeter's prediction and led to the 'atmosphere of universal hostility' of which he wrote.

The explanation of what happened originates in Schumpeter's understanding of the essential element in capitalism. For most members of the public its definition is limited to individual ownership, and this is also true of many economists, as their espousal of the Efficient Markets Hypothesis indicates. But for Schumpeter, something more was needed, which is 'the practice of financing enterprise by bank credit, i.e. by money (notes or deposits) manufactured for that purpose' (Schumpeter [1942] 1997, 167). As early as in his second book, he had stressed that banking is 'creating purchasing power out of nothing' (Schumpeter [1911] 1934, 73). Marx had earlier used almost the same phrase about the surplus value created by workersfor their employers (Marx [1889] 1995, 146) and he in turn was building on Ricardo's distinction between 'use-value' and 'exchange value.' Also, well before Schumpeter, the idiosyncratic political scientist Dunning Macleod, who J. R. Commons credited with founding institutional economics, had written that 'a bank is not an office for "borrowing" and "lending" Money, but it is a manufactory of Credit' (McLeod 1889, 594).

The ability to 'create money from nothing' is such an enormous and dangerous power for anyone to be allowed to deploy, that it obviously has to be subject to the strictest constraints. Even such a strong believer in individual liberty as Adam Smith wrote that 'these exertions of the natural liberty of a few individuals, which might endanger the security of the whole society, are, and ought to be, restrained by the laws of all governments' (Smith [1776] 1976, 344). Traditionally, the most important of such restraints on those who traded in money was the fear of bankruptcy, because their entire fortunes were at stake in every loan or investment they made, 'to their last shilling and their last acre.' Their own interest forced them to be cautious in their funding of manufacturing, of trading in goods and of technological innovation. 
Over time, however, this discipline was abandoned by extending the law of incorporation with limited liability, a social invention of enormous value for economic performance in other fields, to finance. Although this is one of the greatest changes in the history of money, it has scarcely been adverted to, as can be confirmed by reference to the index in any economics textbook. In Goetzmann and Rouwenhorst's comprehensive study of 'the financial innovations that created modern capital markets' (2005) for example, there is just a single reference to any form of 'liability' in the detailed index, and this relates only to the 1602 Dutch East India Company. Schumpeter himself did not advert to the importance of this change.

The fulfilment of his forecast of the replacement of capitalism by socialism is therefore due in the first instance to the progressive inability of finance to do genuinely productive work according as the discipline of individual unlimited liability was relaxed; and in the second instance to the hubris of politicians and civil servants in thinking that this discipline could ever be replaced by any form of regulation they could deliver. The world now knows to its cost that bankers only listen to laws that have teeth, not to exhortations. Moreover, the fact that seven of the most famous banks in the world have admitted massive breaches of US sanctions designed to inhibit Iran from developing an atomic bomb, acts of treason against world security, confirms that the search for corporate banking profits is now without constraint.

What follows begins by discussing how the individual property rights system of Europe from the fourteenth century paved the way for capitalism, resulting in beneficent cycles of technological development which were chronicled and analysed by Schumpeter. It then shows how these were replaced by financial cycles, each of which led to crashes, and explains how the legal changes which made this possible were the result of growing domination of democratic politics by interests. Attempts at bureaucratic control of financiers are then shown from the record to be intrinsically futile. Finally, the case is made that when Governments bailed out banks instead of letting them fail, they were turning their backs on capitalism and proving Schumpeter right in his forecast that it would be replaced by socialism.

\section{Institutions matter}

The difference between 'the West and the Rest' (Ferguson 2011, 11; see also McCloskey 2006, 2010) was caused in the first instance by individual property ownership. These rights were the invention of the Greeks, and the poor natural endowment of their environment underlines how unique was the power of such rights to direct human creativity into the generation of wealth. The culture of 'The Glory that was Greece' led to the spending of this wealth on 'liturgies,' gifts to beautify their cities and to support multiple religious cults. Their values explain why, although the Greeks knew that steam had power, they used it for nothing more than opening heavy temple doors. Within a different system of values in the England of the eighteenth century, the same information, also in a context of dispersed individual ownership, enabled James Watt obtain Matthew Boulton's financial backing to innovate his separate condenser invention. This transformed the efficiency of Newcomen's steam engine to facilitate access to coal and so greatly accelerate the industrial revolution. 
Boulton spent his own money on this, and it owed nothing to bank lending, but the subsequent spread of steam power all over the world was indeed made possible by financiers who 'created money out of nothing,' as Schumpeter noted.

There is obviously an intimate connection between institutions and law, which can be viewed either as Keynes or Marx did. Keynes ended the General Theory with the hope that it would change economic thinking because 'soon or late, it is ideas, not vested interests, that are dangerous for good or evil' (Keynes 1936, 384). From such a standpoint, institutions would be shaped by laws expressing ideas. Marx, who is the ultimate founder of the sociology of knowledge, thought the opposite: that laws and ideas were no more than reflections of economic realities on a psychic plane.

Schumpeter's intellectual debt to Marx in this area is visible in three examples. Money can scarcely exist at all in the absence of law which establishes property in it, yet he wrote that it 'is as little a creature of the law than is any other social institution' (cited in Arena and Dangel-Hagnauer 2002). He did not advert to how much each of the business cycles discussed in the book he published in 1939 depended upon improvements in the laws protecting investment in technological innovation (Kingston 2006). Most remarkably, his comment about the crucial decision that freed bankers from the only discipline they have ever been shown to respect, the fear of bankruptcy, was that

the definitive victory of limited liability is simply another instance of institutional change that merely formulated the logic of an economic situation ...the legislative change is of comparatively small importance in such cases (Schumpeter 1939, 307).

As will be shown below, legislative change can actually be of supreme importance, as it was in this particular instance. Keynes's approach makes more sense of capitalism in its earlier stages, but that of Marx as articulated by Schumpeter becomes progressively better at explaining it when legislation increasingly becomes shaped by interests rather than by visions of the public good.

\subsection{Invisible and visible hands}

All property rights only come into being because there is a government which sets their conditions and limits through laws and makes arrangements for their enforcement. Otherwise, there is only the law of the jungle or collectivism. Only positive law makes markets possible, and Adam Smith's 'invisible hand' can only operate because of it. This is what 'leads an individual who intends only his own gain to promote an end which was no part of his intention,' which 'frequently promotes that of the society more effectually than when he really intends to promote it' (Smith [1776] 1976, 456). Believers in the idea of spontaneous order, such as Hayek, push Adam Smith's idea of the 'invisible hand' further than it can stand, or indeed was intended by Smith to stand.

As Edward Cannan wrote of Smith's theory, 'the working of self-interest is generally beneficent, not because of any natural coincidence between the self interest 
of each and the good of all, but because human institutions are arranged in directions in which it will be so' (Cannan 1913, 331-333, emphasis added). As already stressed, the relevant institutions are individual property rights, whose unique value is that they can civilize self-interest by forcing it to serve the public good also. They can, but they need not. Smith was able to write as he did because he could take the property rights (the 'human institutions') of his time for granted, as indeed Schumpeter did much later. These had evolved in humane directions from the absolute rights of ancient Rome (White 1964, 65) and were well established, particularly in England, when Smith was writing. Not alone can markets only exist because of them, the kinds of markets there will be, depend upon the kinds of property rights there are. To the extent that we can get the relevant laws right, they have proved to be the most effective of all means for enabling human creative energy generate wealth.

However, such rights can never be other than imperfect. As John Stuart Mill wrote, 'the laws of property have never yet conformed to the principles on which the institution of private property rests' (Mill [1848] 2004, Book II, Ch. I). These principles require the formulation of laws of property in terms of the public interest, whereas in recent decades they have been increasingly shaped by what Mancur Olson called 'distributional coalitions.' These lobby in democratic societies for laws which suit them, their objective being to modify the pattern of property rights. Such groups 'have the incentive and often the power to prevent changes that would deprive them of their enlarged share of the social output' (Olson 1982, 144-5). This process of capturing property rights is an evolution towards Max Weber's 'political capitalism,' which he defined as 'exploitation of the politically oriented events and processes which open up opportunities for profit' (Weber [1921] 1978, 164-66). Or, as we would now call it, rent-seeking.

To the extent that this capture is allowed, legal institutions are distorted, and the working of the 'invisible hand' is no longer beneficent. There will always be need for State action to compensate for failure of markets, but politicians or bureaucrats (who are invariably under pressures to intervene) tend to cry 'market failure' too early, so as to justify action on their part. Their proper task, instead, is to modify property laws so as to allow markets do their work.

Ignorance of the role institutions play was expressed at its worst in the Efficient Markets Hypothesis-'belief that market processes are naturally stable, and that results would be even better if constraints were relaxed' (Wray 2009, section 2). Its enthusiastic espousal by so many academic economists contributed in no small degree to the contemporary financial debacle (see Frydman and Goldberg 2011). The principle that markets exist only because of laws which confer property rights, and that there is no 'natural coincidence between the self-interest of each and the good of all' was progressively forgotten over much of the last century.

\section{Bourgeois achievement}

As long as individual property rights were shaped in the public interest, however inadequately, they were amazingly productive of wealth. McCloskey (2010) uses a 
factor of 18 for the amount of this available to an individual in a modern Western country now, compared with a couple of centuries ago. The owners of these individual property rights are the bourgeoisie, and they have never had a more formidable critic than Karl Marx, yet Schumpeter pointed out that the Communist Manifesto contained 'a panegyric upon bourgeois achievement that has no equal in economic literature.' Writing to celebrate the centenary of this famous document, he urges us to

observe, in particular, the emphasis upon the creative role of the business class. Never, I repeat, and in particular by no modern defender of the Bourgeois civilisation, has a brief been composed on behalf of the business class from so profound and so wide a comprehension of what its achievement is and what it means to humanity' $(1949,209)$.

He then cites the Manifesto to the effect that

The bourgeoisie has been the first to show what Man's activity can bring about. It has accomplished wonders far surpassing Egyptian pyramids, Roman Aqueducts and Gothic cathedrals ...[and] created more massive and colossal productive forces than all previous generations put together. Subjection of nature's forces to man, application of chemistry to industry and agriculture, steam-navigation, railways, electric telegraphs, cleaning of whole continents for cultivation, canalization of rivers, whole populations conjured out of the ground-what earlier century had even a presentiment that such productive forces slumbered in the lap of social labour? (Marx and Engels [1849] 1967).

\subsection{Schumpeter's 'innovators' and 'entrepreneurs'}

This unique achievement was brought about, not just by individual property rights, but by the development of means of using them to bring about economic innovation, and these means are what Schumpeter called 'creating purchasing power out of nothing.' It is remarkable, but largely unnoticed, that he did not call the individual who takes the initiative about turning information into concrete reality, the 'innovator,' but the 'entrepreneur.' He gave the title of 'innovator,' not to the moving spirit in an enterprise, the individual with the imagination to see the possibility of something new, and the energy to make it happen, but to whoever provides the money for it. That is, his innovators were Boultons rather than Watts. He even goes so far as to claim that 'the entrepreneur is never the risk bearer' (Schumpeter [1911] 1934, 134). It is true that at the very least, the entrepreneur risks his opportunity cost, but nothing changes the fact that for Schumpeter the provision of investment was more important even than the provision of ideas and energy.

Schumpeter observed that most economists up to the time of the younger Mill, failed to distinguish between financing and innovation, because their typical active agents dealt with both at the same time. As individual property rights became more widespread, diversified innovations became possible through rich individuals investing in them, often to develop their own businesses. Then, as trading in 
money developed, the number of possible sources of it to back new ideas was multiplied through growth in the number and size of banks (Schumpeter stresses in particular the development of joint stock banking in Germany) leading him to assert that

The banker, therefore, is not so much primarily a middleman in the commodity 'purchasing power' as a producer of this commodity...he has either replaced private capitalists or become their agent; he has himself become the capitalist par excellence. He stands between those who wish to form new combinations and the possessors of productive means. He is essentially a product of development, though only when no authority directs the social process. He makes possible the carrying out of new combinations, authorises people, in the name of society as it were, to form them. He is the ephor of the exchange economy (Schumpeter [1911] 1934, 74).

(The Ephors were elected magistrates who supervised the kings in Sparta, so Schumpeter's analogy is with bankers effectively deciding which 'new combinations' will be formed). As he envisaged it, the financiers' task of creating purchasing power is 'for the purpose of transmitting it to the entrepreneur' (Schumpeter [1911] 1934, 107). Unlimited liability made them cautious about their lending and investments, but they were still able to finance innovation. For example, McLeod attributes Scotland's disproportionate role in the industrial revolution to its system of Cash Credits, directed specifically towards this:

These are not founded on any previous transactions; nor are they for the purpose of transferring existing commodities. They are created for the express purpose of bringing new products into existence ...the invention of cash credits has advanced the wealth of Scotland by centuries ...(McLeod 1889, 622).

Even if lack of incorporation limited the size of banks, they were well able to handle flotations that would be large by todays standards, such as that of Guinness by Baring's (then still a partnership) in 1888.

\section{Banking is different}

Throughout the period when Schumpeter's thinking was being formed, banking was still being carried on overwhelmingly through partnerships, and the gold standard was unquestioned, so that he could take the contemporary pattern of property laws for granted. This stable system was based upon a general belief that 'dealing in money is different' which is as old as property rights themselves, and is illustrated in the prohibitions against usury in the Jewish, Islamic and pre-Reformation Christian worlds. Even when the taking of interest on loans came to be permitted in the West, dealers in money had to face restrictions which did not apply to those who traded physical goods. Adam Smith approved a legal cap on interest rates on the ground that this would deny loans to 'prodigals and promoters,' who were the only people 
who would be imprudent enough to borrow at high rates. Usury laws even limited the discount rate that the Bank of England could offer on commercial bills until 1833 (Ferguson 2008, 54).

The first of two ways in which banking is different from manufacturing or trading physical goods relates to the stocks which need to be carried by any business. Except for banking, these are a necessary cost, whereas for a banker they actually earn money, because he can hold them in the form of interest-bearing deposits with other parties, even if only at overnight rates. This gives dealing in money a significant advantage in terms of profitability over all other kinds of business. The second reason is even more - in fact, vastly more-important. If a manufacturer or a trader wants to expand his business beyond his resources, he must persuade someone else either to invest in it or to lend him money. A banker can expand simply by advancing money beyond what would be justified by his assets. Ricardo had noted that the distinctive function of a banker 'begins as soon as he uses the money of others, ' an activity which Macleod $(1889,584)$ expressed succinctly (for him, of course, 'money' meant bullion):

When bankers bought or discounted Bills of Exchange, they bought them by issuing their own Credit, and not with money. And experience showed that they could multiply their Bills of Credit several times exceeding the quantity of money they held, and thus for all practical purposes multiply the quantity of money in circulation. Thus, the essential business of a "Banker" is to create and issue Credit to circulate as Money.

This means, according to Schumpeter, that at the macro level

in real life total credit must be greater than it could be if there were only fully covered credit. The credit structure projects not only beyond the existing gold basis, but also beyond the existing commodity basis' (Schumpeter [1911] 1934, 95).

'Expanding the credit structure' is exactly what Schumpeter's 'innovator' does when he finances an 'entrepreneur's' project, and he can go on leveraging his assets in this way as long as his reputation amongst those who do business with him remains intact. When he goes too far, however, or if there is some external shock, this reputation will come into question, and a run on his bank will start, most likely leading to its collapse. When this happens widely enough, there is recession or depression in the whole economy.

\subsection{Financiers under legal control}

A banker's power to lend beyond his resources in secret is so profitable that the temptation to use it is virtually irresistible in the absence of an extremely strong institutional deterrent. Historically, this was provided by the fear of personal bankruptcy through the individual unlimited liability of all traders. Liability limited to the amount of an investment was only available for shares in the Bank of England or in the Chartered banks in the United States, in the Chartered Overseas Trading 
Companies of different countries, and in the canal and railway companies, each one of which needed individual legislation. The formation of joint stock companies without a Royal Charter was banned by law in England in 1719 by the Royal Exchange and London Assurance Corporation Act (6 Geo I, c. 18). Even after this was repealed in 1825, all cooperation in business still had to be in the form of partnerships, which carry joint, several and unlimited liability for each participant. Individuals' entire fortunes could be forfeit in the event of failure, and they could actually be imprisoned for debt in the United States until 1833 and in Great Britain until 1869.

Possibly stimulated by the English Act of 1719, specific legislation that made anyone who dealt in money personally liable for losses without limit was passed in Ireland in 1721 (29 Geo. 2 c.16). Further, from 1756, merchants trading in commodities there were not allowed to do banking business as well. And in 1782, when the Irish Parliament passed an Act which provided for limited liability partnerships (something which England did not get until 1907) the privilege was explicitly denied to bankers.

Corporations whose shareholders' liability was limited to the amount of their investment were introduced in the United States almost from the start, and in England in 1855 , but only for manufacturers and commodity traders. It was amazingly successful and was largely responsible for a huge upsurge in economic activity: 'Britain went from seven hundred to ten thousand business corporations in twenty years' (North et al. 2009, 219). Moreover, it was copied in almost every country in Europe within a decade (Ripert 1946). Significantly, however, bankers were excluded from this privilege, as they had been from the Irish legislation of 1782. Netherlands bankers also had to operate under unlimited liability until 1863. In Sweden, the private banks which were permitted to exist from 1824 had the condition of unlimited liability imposed on them until 1863 also. The same condition operated in Japan up to 1886. Before the unification of Germany in 1871, the liability of the main shareholders in some Prussian banks was without limit, although this did not apply to less important shareholders. As long as such levels of discipline were in force, banks remained small, because each partner needed to work actively in the business to ensure that he was fully aware of every aspect of it, since his whole fortune was involved. The risks they undertook were carefully calculated because so much was at stake for their owners, and they were far from ever being 'too big to fail.'

A second group of countries did not require bank owners to have their entire wealth at risk, but nevertheless faced them with losing more than they had invested in the event of failure. In the United States from 1863 to 1914, in Australia from 1840 to 1893 , and in Canada from 1870 to as late as 1935, shareholders could lose up to twice their investment in a bank if it failed (Turner 1988, 138-149). This penalty was not nearly as great a deterrent to imprudent lending as unlimited liability, so that bank failures in the US were significantly more common than they were in Europe. Those failures were the main reason for the establishment of the Federal Reserve there in 1912-13. Possibly because of belief in what this new institution could do, even the low penalty for failure (double the investment) was eliminated in 1914. 


\section{5 'Schumpeterian' capitalism}

Schumpeter discussed the outcome of finance provided under these conditions in Business Cycles (1939). This was sub-titled A Theoretical, Historical and Statistical Analysis of the Capitalist Process, and is an extensive history and analysis of the activities so highly praised in the Communist Manifesto. It is more than symbolic that the end-date of this study is 1929, the year of the Great Crash, because the three cycles he studied were technological, when money 'created out of nothing' was invested in ways that could produce genuine returns and benefits to the public. The period could even be designated as that of 'Schumpeterian' capitalism. His interest in technology had been foreshadowed in his very first book, written while he was a financial Consultant in Cairo. In this, he made the case for bringing 'practical business operations in the broadest sense ... [which] up to now was as good as in the hands of the engineers' into the scope of economics (Schumpeter [1909] 2010, 446-51). Business Cycles reflects the development of his interest in the causes of the forward economic thrusts he had begun to study three decades earlier, and their growth, decline and exhaustion. It also contains material on the first long financial cycle, which came to an end in 1929, which otherwise might have been included in the book he started on Money and Currency. It has been suggested that he did not continue with this because he felt he had been pre-empted by Keynes's (1930) Treatise on Money.

In Business Cycles Schumpeter analysed 'the age of the industrial revolution, 1785 -;' 'the age of steam and steel, 1848-1895;' and that of 'electricity, chemistry and motors, 1895-1929.' After Schumpeter, two further non-financial cycles or forward thrusts are identifiable, one based on mass marketing, and a second on the exploitation of civilian markets for inventions made during the 1939-45 war. (Some scholars consider that the explosive growth of the information technology industries, which originated in the electronic computers invented for wartime codebreaking, justifies being characterized as a cycle on its own, because it led to what was known as the 'dot-com boom'). The special characteristic of post-war prosperity was that

In the three decades following World War II, the United States dominated commercial innovation using spinoffs of defense innovations which were developed to serve the domestic market ... Although the initial objectives were of course military, the information generated became the basis of entire new industries after the war, apart from delivering equally valuable incremental improvements in already existing products and in their methods of manufacture (Kash 1989, 14).

The importance of these ranged from the antibiotic revolution, which began with the massive investment in penicillin (second only in scale to that in the atomic bomb) made directly by the United States government, to the magnetron, which is the heart of both radar and the microwave cooker. American Research and Development Co., founded in Boston in 1946 by General Doriot to exploit these new technologies, was the start of the modern venture capital industry, which became particularly important in the later 'dot-com' boom. 


\subsection{From technology to financial innovation}

Largely parallel with this list of technological cycles were two cycles based on financial innovations, both of which came to disastrous ends. Much research has confirmed that in the second of these, there has been a catastrophic shift from technology to financial activity in all OECD member countries. Typically, work on US data by Philippon and Reschef (2009) shows that in the years immediately after World war II, when technology remained dominant, the financial sector there accounted for no more than 10-15\% of all corporate profits. At the peak of the recent boom, its proportion surpassed $40 \%$.

They further confirm this from movements in the remuneration of those who worked in the financial services sector in the United States during the twentieth century, relative to other non-farm employees. From the starting point of the research in 1909, 'financial jobs were relatively skill-intensive, complex, and highly paid until the 1930 s and after the 1980 s, but not in the interim period.' The ratio of financial wages to non-farm private wages was negative until about 1960, reflecting the postwar surge in technology discussed by Kash, but then grew rapidly to a peak of 1.7.

This pattern was repeated in other advanced countries, such as in the relative growth of financial assets in Britain. For almost a century, and as long as the country had a substantial manufacturing base, banking sector assets were about half the level of British GDP, but from about 1960, they began a steep climb to a level of more than five times GDP during the recent boom (Sheppard [1971] 2006, supplemented by Bank of England data).

\subsection{How did bankers' liability become limited?}

It was the sudden reversal of these trends from 2009 that resulted in the recession and the unemployment levels that are responsible for the current 'atmosphere of universal hostility' against what is still considered to be capitalism. To understand how this came about, it is first necessary to explore how financiers escaped from the constraints which had made the links between Schumpeter's 'innovators' and 'entrepreneurs' so productive.

As long as bankers were under the constraint of unlimited liability, self interest forced them to invest in technology and other activities that could produce real wealth that would last after the capital had been repaid. As noted above, from 1855 in the UK and from a few years later in other European countries, their clients in manufacturing and trading could do business with their liability in the event of failure limited to whatever they had invested. UK legislation explicitly excluded bankers from the privilege, but a version of it was offered to them in 1858. However, this did not limit the liability of shareholders for uncalled amounts of partly-paid shares. As this type of shareholding was common, no bank of significance took advantage of it, fearing that the protection offered did not outweigh possible impairment to the standing of their credit with the public (McLeod 1889, 933).

Bankers' assessment of the limited value to them of the 1858 Act was proved correct by the disastrous collapse of the City of Glasgow Bank in 1878, which in itself illustrates what a powerful deterrent unlimited liability could be to excessive financial 
risk-taking. The issue price of each share in the bank had been $£ 2,850$, of which only $£ 100$ had to be paid on subscription, leaving a contingent liability of $£ 2,750$ for each share. In the liquidation, this unpaid proportion was immediately called in, but of the bank's 1859 shareholders, only 254 were able to meet the demand.1605 shareholders were consequently made bankrupt in a process which ensured that not a single one of the note-holders or depositors of the bank lost a penny (Turner 1988).

A new Act limiting liability as a result of such Calls was passed quickly in 1879, and this time bankers flocked to take advantage of it. The outstanding exception was Baring's, the most prestigious private bank in London, whose partners decided that limited liability was inappropriate to the unique scale and prestige of their bank. Baring's itself became seriously over-extended in South America in the 1890s, to the extent that the Bank of England, fearing the grave damage its collapse could do to the prestige of the City of London, organized a bail-out which preserved the depositors' and bond-holders' interests. However, the cost to all the partners, whose entire personal wealth had to be contributed to the settlement because their liability was without limit, was devastating. Unsurprisingly, after the reconstruction of the Bank, they took care to make it a limited company, so that when Baring's became insolvent for a second time a century later, it was their depositors who suffered most.

The Bank of England was a de facto central bank, and its action in the Baring's case foreshadowed the 'last resort' role for such banks, the first of which was the Federal Reserve in the United States, established in 1912. It was also the first case of a response based on a bank being 'too big to fail' which has been such a feature of pressure on governments to intervene in the current crisis.

\subsection{US bankers out of control}

Lack of effective discipline on bankers is the primary reason why the great financial crash of 1929 originated in the United States. The stock exchange meltdown in that year owed everything to the ease with which buyers of stocks and shares had been enabled to operate 'on margin' through bank loans. These were made so freely available during the 1920s that when the market collapsed, thousands of banks failed. The losses to depositors caused the United States Government to set up the Federal Deposit Insurance Corporation to prevent this happening again. Also, the Pecora Hearings on the causes of the crash led to the Glass-Steagall Act of 1933, which prevented banks in the U.S. from being involved in many kinds of investment activity (Perino 2010).

However, Glass-Steagall was repealed, partially in 1980 and completely in 1999, permitting a new wave of risky investment involving the creation of money from nothing on an enormous scale. This time, the power of computers combined with instant global communication enabled bankers to develop a bewilderingly wide range of financial instruments, such as derivatives, credit default swaps, mezzanine finance and new securitizing techniques (for description and discussion, see Wray 2011). These expanded credit to an unprecedented extent in what Minsky (1982) called 'money managed capitalism.' This involved wholesale 'pyramid selling,' in which investors were led to believe-and led themselves to believe-that asset values would grow indefinitely. It was the extreme case of what Schumpeter had described 
as 'dematerialised, defunctionalised and absentee ownership' (Schumpeter [1942] 1977,142 ) and which he forecast would destroy the social acceptance of capitalism, as the inevitable crash did.

Both the imposition of effective financial regulation in the US in the 1930s and its staged repeal from the 1970s are clearly visible in Philippon and Reschef's data cited above. US deregulation was internationally contagious, illustrated by London's 'Big Bang' in 1986. Salomon Brothers then started a trend in banking by changing from being a private partnership to PLC ownership. The inability of the large numbers of shareholders in these new banking Corporations to exercise any effective control over their managements, allowed quite new and extraordinary risks to be taken. The result was that firms such as Lehman Brothers and Bear Stearns, which had survived the Great Depression as partnerships, collapsed as corporations in 2008. A particularly unfortunate aspect of corporate banking is the extent to which employees apparently have to be free to deal on behalf of the firm without reference to its owners or even to its senior managers, as some of the most spectacular failures in the recent bubble have reflected. The second failure of Baring's bank in London was due to activities of a single trader in the Far East that its Board did not know (or did not want to know) about. Even more recently, it appears that Morgan Stanley's top management was completely unaware of how a tiny group of its traders lost it up to $\$ 6$ billion.

All of this was inevitable and was in fact foreseen. The Head of the Federal Reserve Board, Paul Volcker, argued prophetically that the creeping repeal of the Glass-Steagall Act 'would recklessly lower loan standards and allow bad loans to be marketed to the public' - exactly what actually happened in the U.S. subprime property debacle. In fact, there exists a list of no fewer than twelve authors whose published predictions meet stringent conditions for having forecast the crisis (Bezemer 2009).

\section{Schumpeter on bureaucracy}

Once the law was changed so that financiers no longer had their whole personal wealth at stake if their loans or investments went wrong, governments attempted to discipline them through 'Regulation' by their civil servants. However, nothing has emerged with more clarity from the worldwide financial crisis than the complete failure of this, which is quite intelligible from Schumpeter's own discussion of bureaucracy, especially in his 1942 book. Although his personal experience of it was in Austria from his time as Finance Minister there, his ideal was the Prussian civil service, which he described as 'supremely competent, utterly uncorruptible, completely independent of politics' (Schumpeter 1939, 346). The main European countries had developed bureaucracies with quite a degree of independence of politicians during the nineteenth century. These had deep roots, going back to their common prototype, the Papal civil service of the middle ages. As he pointed out:

They are the product of a long development which started with the ministeriales of medieval magnates (originally serfs selected for administrative and military 
purposes who thereby acquired the status of petty nobles) and went on through the centuries until the powerful engine emerged which we behold today. It cannot be created in a hurry. It cannot be "hired" with money. But it grows everywhere, whatever the political method a nation may adopt. Its expansion is the one certain thing about our future (Schumpeter [1942] 1977, 294).

The bureaucrats he had known and of whom he approved, came from a 'social stratum of adequate quality and corresponding prestige ...not too rich, not too poor, not too exclusive, not too accessible' (ibid.). It was this kind of person he obviously had in mind when he wrote that

[D]emocratic government in modern industrial society must be able to command ... the services of a well-trained bureaucracy of good standing and tradition, endowed with a strong sense of duty and a no less strong esprit de corps [and this]... must also be strong enough to guide and, if need be, instruct the politicians who head the ministries. In order to be able to do this it must be in a position to evolve principles of its own and be sufficiently independent to assert them. It must be a power in its own right (op. cit., 293).

From today's standpoint, this may sound altogether idealistic, but Schumpeter gave as an example how in relation to railway development, the Prussian civil service 'did much in many ways besides exerting discretion in chartering, to prune promotion, to sober finance and to steady advance' (Schumpeter 1939, 346). The German patent Act of 1877 also illustrates how such a civil service could articulate the public good in the face of private interests. Wernher Siemens, one of the founders of the great engineering firm, had grasped that the development of electricity needed appropriate patent protection, and had actually gone into politics to bring this about (Heggen 1975). However, he did not get all his own way, because competent civil servants resisted some of his proposals on public interest grounds. The resulting balance in the legislation enabled it to be a most fruitful factor in Germany's industrial development.

Possibly because of his move to Harvard, Schumpeter does not seem to have adverted to the extent to which the social classes from which the independent-minded civil servants he admired had been drawn in Europe, were destroyed by World War I and the hyper-inflation which followed it. Those lost had to be replaced by people who were totally dependent on their jobs, like the large numbers recruited in the United States by President Roosevelt to carry his New Deal through, and of whom Schumpeter could scarcely have been more critical:

[T] here was no experience, no esprit de corps, no clear idea even of what a civil service is and what it can and cannot do. No less inexperienced-to the point of not seeing the fundamental administrative problems at all-were the men in whose hands that unwieldy apparatus was put. The tact, the reserve, the savoirfaire which are second nature to a seasoned bureaucracy were alike absent. .. in consequence, that sense of indefinite threat was immeasurably increased (Schumpeter 1939, 1048). 


\subsection{Failure of bureaucratic regulation}

'No clear idea even of what a civil service is, and what it can and cannot do.' This has been all too visible again in the modem United States and Europe in the hubris of regulators in thinking that they could control bankers. The new type of bureaucracy has shown itself to be unable either to deal with financiers or to resist pressure from its political masters. The kind of regulation which financial dealing needs will always be impossible for people who depend on their salaries. The phenomenon of 'regulatory capture' whereby regulators fall under the power of those they are meant to be supervising, has been well-known to economists since Stigler (1971). In the United States, too, there has been a particular tendency for banks to be able to place their own people in positions of regulatory power. There and elsewhere, the poachers are able to hold out the prospects of future jobs at multiples of their salaries to influence the gamekeepers. Because the poachers are the innovators, the gamekeepers can never be ahead of them, but in fact struggle hopelessly to keep up.

Above all, the imbalance in motivational terms between the two parties is crucial. Regulators, even if people of personal integrity, are public employees, and there is no reason why they should be passionately motivated to study and understand the subject-matter of their task. Nor can outcomes, whether good or bad for the public, affect their personal financial situation within the bureaucracy more than marginally. Consequently, they can never be a match for those they are supposed to regulate, extremely highly-paid individuals who eat, sleep and dream their project in hand. The process which selects these financiers puts a premium on proved earlier success, but their opponents are civil servants who have attained their positions largely through seniority, since no bureaucracy can operate on a basis of comparable individual responsibility. In such contests, even if the regulators do their best, they can never win. They have been given a task they simply cannot perform.

\subsection{Central banking}

A main instrument used by Governments in trying to replace law by bureaucratic intervention to control the 'creation of money from nothing' has been their Central Banks. The evidence of their complete failure to do this is compelling. For example, in the US in 1951 the ratio of banks' liquid reserves to deposits was $11.5 \%$, but 50 years later, in 2001, it had fallen to nearly one sixtieth of that level (Griffith-Jones et al. 2010, 134, 145). This indicates the extent to which banks were allowed to leverage their assets into loans. Even to-day, only one-tenth of the US money supply is subject to reserve ratios, because these apply only to household deposits, not corporate deposits: 'fundamentally, banks manage to evade most of those controls ...we see what is [supposed to be] a control mechanism but actually is a response to what is happening in the private sector' (Keen 2012, 9). Clearly, so far from disciplining their lending, US banks' ability to look to the Federal Reserve for funds enabled them to expand it massively. 
As well as this, a great part of the 'creation of money from nothing' during the recent boom has been carried on in what is called the 'shadow banking sector,' outside the scope of traditional banking regulations (Wray 2011, 9). In fact, so little was known about it (and even less understood, even by participants) that it was probably intrinsically impossible to regulate exogenously. Unlimited liability, which regulates endogenously through the fear of bankruptcy, has the great merit of automatically constraining even the risks that neither a lender himself nor anyone else is able to understand.

\section{Financial innovation replaces technology}

The legal changes which stimulated Schumpeter's cycles of technology were a progressive strengthening and widening of protection for investment in genuine economic innovation, whereas both financial cycles reflect relaxation of traditional legal controls on the generation of credit. Dealing in money was given the same property rights as dealing in any other commodity, when in fact it needs quite different institutional arrangements. Allowing bankers to escape from the property laws that used to control them has had fatal results for capitalism, which was only able to operate as long as capitalists were denied the power to decide their own working conditions.

The Philippon and Reschef research shows how greatly the ability to create previously unimaginable amounts of purchasing power from nothing, increased rewards for employees who had the skills to devise and operate financial innovations. This of course attracted money, talent and energy out of technology and other kinds of business into finance. The UK suffered more from this than other industrialised countries in Europe because the City of London is such an important centre for financial dealings, and thus provided an alternative outlet for money and talent. For example, a wide range of British engineering firms fell victim to take-over by Arnold Weinstock's General Electric Co., precisely because their managements had a timescale that was adapted to technological innovation but the financial institutions which held the bulk of their shares did not. At the end of the Weinstock era, GE's main research laboratories at Wembley were only allowed to work on projects for which the start of returns could be foreseen within five years - probably the limiting case of the impact of the shift towards financial innovation in shortening the time scale for investment in technology to be expected to give a return.

It has long been observed that stock exchange pressure on firms to show constantly increasing returns on a quarterly basis has had the effect of shortening firms' time horizons generally. In any event, the attraction of investing in radical technological innovation is low for publicly-quoted firms, because it involves uncertainty as well as risk, and even when it is successful, it produces results only in the long term.

The now widespread payment of executives through stock options reinforced this movement away from longer-term investments, because it aligns the interests of firms' managers with those of stock traders, who are primarily concerned with calculable risk and the short term (Lazonick 2009). For investment in radical technological innovation, enough information even to allow the calculation of risks may only become available after much time and commitment of resources. The world's 
first commercial jet airliners, the de Havilland Comets, were well into airline service before it was learned from their catastrophes that not enough had been known about metal fatigue at the time they were being designed and built.

\section{1 'Creative destruction'}

One of Schumpeter's best known concepts is that of 'the perennial gale of creative destruction' (Schumpeter [1942] 1997, Chapter 7) whereby firms which do not innovate continuously are replaced by new ones 'built by new men with new ideas.' This phenomenon was evident from the beginning of the industrial revolution up to the end of Schumpeterian capitalism. Watt could never bring himself to accept that, after his own breakthrough with the separate condenser, the future was not with the low steam pressures he used, but with high-pressure steam. This meant that other firms replaced Boulton and Watt. Neither could Edison accept that electrical power transmission would use Westinghouse's alternating current, not his own direct current system. And Charles Parsons, the innovator as well as the inventor of the steam turbine, went on record that the gas turbine was intrinsically impossible (Appleyard 1933, $174,178)$. The entire development of aircraft jet propulsion consequently passed to other firms.

The most important function of banking, in Schumpeter's view, was to finance these 'new men' with their 'new ideas,' but to the extent that banks fail to do this, the only remaining source of money for innovation is the retained earnings of established firms. Consequently, these firms have little to fear from creative destruction. Success in any business inevitably produces reluctance to move on to the next stage in its technology, partly because this is likely to reduce the value of investments already made, partly because as firms grow larger they become more bureaucratic, and partly because investment in innovation involves uncertainty, whereas if the money is put instead into incrementally expanding the existing business there is only risk and probably low risk at that. Schumpeterian capitalism ensured that this reluctance did not matter to society as a whole, because it provided incentives to bankers to provide finance for those anxious to take up new concepts and develop them, to the detriment and even demise of incumbent firms,

The shift to financial innovation emasculated this fundamental element of capitalism and reduced its unique capacity for encouraging new technology. The contemporary illustration of Kodak's destruction by firms which exploited the digital photography whose potential it so largely ignored, is unfortunately now all too rare. Delivering the market power which depends upon capability, Corporation law has evolved in ways that value size over innovative capacity, and competition policy has failed to prevent the growth of oligopolies. Investment in psychological assets, or reputation, through advertising and marketing (persuasive market power) can develop barriers to entry so strong as to make many fast-moving consumer goods fields into 'informal cartels.' This has the additional advantage of looking like competition to Regulators. 'Specific' market power, in which the entry barrier is provided by law or edict, as in intellectual property, should be the means of facilitating the foundation of new firms to threaten the established ones with competition from new technology. Instead, the evolution of the laws of intellectual property has made this into little 
more than a reinforcement of the other two types of market power. It is now anything but a means of stimulating creative destruction, and hence of enabling capitalism to work. For example, no less than two-thirds of all the profits made from patents throughout the world now accrue only to a single industry, chemicals (Bessen and Meurer 2008).

\subsection{Asian competition}

While Western firms were abandoning long-term research and development in many areas, competing firms in the Far East were taking it up. Although the results of this are manifest, this shift 'from the West to the Rest,' can be quantified by two studies made possible by special features of the United States patent system. The first of these is 'Interferences.' If two patent applications reach the Office close together in time, a special enquiry had to be held as to the actual date of invention. The database of these enquiries is consequently a unique source of objective information on the process of worldwide simultaneous invention. Most of the parties in these records are amongst the largest firms in the world, and their inventions are of course their most advanced technological efforts. Between 1991 and 1994, there were 270 Interferences involving a non-United States party, and $119(44 \%)$ of the latter were Japanese.

What is most remarkable is that in no less than 57 of these 119 cases, the competing party was also Japanese. The absence of a European or United States competitor from so many cases where two Japanese firms reached a technological goal at more or less the same time, reflects a remarkable level of dominance of the related technologies by Japanese firms. In these cases, no European or United States firm was close enough to the forefront of particular areas of technology to be involved in the Interference process (Kingston 2004, 213).

The second feature of the United States patent system which enables reliable 'like for like' international comparisons to be made, is the discount the Patent Office gives to 'Small Entities.' Records of these show that from 1994 to 2003 Taiwanese inventors obtained more patents in the US than inventors from any country other than the US itself. Their totals are dramatically higher than those from either Japan or Germany (Kingston and Scally 2006). In fact, ongoing work on this database for the years since 2004 indicates that inventors from this single Far Eastern country have now passed out all 27 EU countries combined.

\section{Schumpeter on democracy}

It remains to be explained how bankers were allowed to escape from the only constraint that was ever able to help them resist the temptation to "create money from nothing' excessively. The answer is to be found in the way in which popular government developed. Democracy was Schumpeter's third topic in his 1942 book, and he defined it as 'that institutional arrangement for arriving at political decisions in which individuals acquire the power to decide by means of a competitive struggle for the people's vote' (Schumpeter 1942, 269). A political party is 'a group whose 
members propose to act in concert in the competitive struggle for political power" (Schumpeter 1942, 283).

He was writing too early, however, to be fully aware of the extent to which interests could come to dominate the outcome of this struggle. They have always tried to use their influence to get the laws they want-in George Soros's phrase, 'behind the invisible hand of the market lies the visible hand of politics.' For example, the prohibition on joint stock company formation in England in 1719 was not the result of a wise government attempting to keep business men under control. In fact, it was the very opposite, in that the law was introduced at the behest of the promoters of the South Sea Bubble to prevent rivals sharing in the gains from the investment mania they had provoked (Schumpeter 1939, 248).

Nevertheless, Schumpeter did understand the danger which the capture of government by interests represents for democracy. In one of his least-known works, The Crisis of the Tax State, published in 1918, he wrote of the State that 'It is part of its nature that it opposes individual egoism as a representative of a common purpose. Only then is it a separate, distinguishable social entity' (Schumpeter [1918] 1991, 110). The only way in which the State can fulfil this role is by imposing a system of individual property rights which force 'individual egoism' to serve the public good in following its own interest. However, it does not take long for individuals who are being controlled in this way to grasp how much more they could gain by getting control of the law-making mechanism so as to shape property rights to suit themselves. This then becomes the objective of the individual egoism' which Schumpeter claims the State exists to oppose. The book suggests that even as early as 1918 he sensed that in this dialectical process States were already losing the battle to remain 'distinguishable social entities,' separate from interests.

The reality is that democracy depends upon property. It works where it is a counterweight to wealth that is the result of independent property rights, when it gives power to numbers qua numbers. It fails to work to the extent that the wealth to be counterbalanced has come into being through any form of capture of the power of the State. It has even been shown theoretically that an essential economic prerequisite for any democratic State's survival is that a significant proportion of incomes is independent of its Government (Usher 1981). Rent seeking, which uses the State's power to make money for individuals, therefore undermines democracy.

\subsection{Discriminatory legislation}

It is reasonable to assume that growth in the power of interests over politicians could only increase as the franchise was widened, making politicians more vulnerable to those who could finance them. Benjamin Disraeli was the British Prime Minister who introduced adult male suffrage in 1867, yet he feared what he called 'enthronement of the commercial principle in England' (Monypenny and Buckle 1910, iii. 195). It is certainly the case that financing of politics by interests was progressively more evident after World war I, as was noted by Buchanan and Tullock: 
We may observe a notable expansion in the range and extent of collective activity over the last half-century-especially in that category of activity appropriately classified as differential or discriminatory legislation. During the same period we have witnessed also a great increase in investment in organized interest-group efforts designed specifically to secure political advantage (Buchanan and Tullock 1962, 269).

Politicians became particularly vulnerable to interests once votes could be garnered through spending on public projects, even if these were non-productive, and on expanding public sector employment. Charles Whalen thinks that what he calls 'America's obsession with money and debt' $(2011,345)$ began with Abraham Lincoln's decision to finance the Civil War by borrowing rather than taxation. This precedent has been followed in every difficulty since then. Broadly speaking, public debt used only to be incurred in Western countries to finance wars, but in recent decades the main reason for its expansion has been electoral pressures. Needless to say, this process progressively increases the power which the interests providing money to politicians have over them.

Since Buchanan and Tullock wrote, the expenses of politics have grown at an exponential rate in every democratic country, and politics has become a full time and well-paid profession. In particular, the coming of television and social media escalated the costs of getting elected, making politicians all the more dependent on those who underwrite these costs. Hence the size and dynamism of the contemporary lobbying industry, and it has even been noted by a high-ranking Eurocrat that 'One of the most remarkable shifts in European economic policy governance in the last decades has been the evolution from the "social partners" approach to a lobby-influenced one' (Nowotny 2004). Quite new kinds of property were brought into being through lobbying, many of which extended the value of ownership of shares in corporations. Above all, it was this activity on a massive scale that delivered freedom from effective control to the financial industries. It took no fewer than twelve attempts and millions of lobbying dollars to get the US Glass-Steagall Act repealed.

Consequently, it is not difficult to see why, when those who were lending to them or their banks got into trouble, governments decided that they had no option but to bail them out in vain attempts to continue this lending process. These measures are all at the expense of an economy's capacity for Schumpeterian capitalism, to try to save a financial system which the same Governments had allowed to escape from control.

\subsection{Misleading economic measurements}

Lord Kelvin coined the phrase for nineteenth century science that 'we advance according to the precision of our measures,' and part of the current financial crisis is certainly due to the inadequacy of the ways in which economic activity is measured. The system of national accounts developed in the 1940s by Simon Kuznets seemed to offer scientific precision in this, so that policies came to be assessed by the extent to which they contribute to economic growth as measured in terms of GDP or GNP. 
The difficulty is that these accounts are unable to discriminate between activities (see the Report of the Commission established by France's President Sarkozy: Stiglitz et al. 2009). A financial innovation counts just as much in them as a technological one. The money value of a means of securitizing subprime home loans so that they can be bought as a package by a financial institution, for example, may be the same as that of a new plant variety. Both will come into the national accounts with the same weighting, but whereas the financial instrument will contribute to an eventual slump, the new plant variety could continue indefinitely to help reduce starvation in poor countries. By their inability to distinguish between genuine and 'bubble' economic growth, the inadequacies of the Kuznets system of national accounts contributed greatly to the recent crash by encouraging what Hyman Minsky called the 'euphoric' phase of the bubble, during which rationality is on the way towards being abandoned. No less than $28 \%$ of what was recorded as demand in the US in 2008, for example, was the result of nothing more than increased debt (Keen 2011, 341). The credit rating Agencies have also contributed greatly to the harm: 'their propensity to give high ratings to junk assets is well known, indeed ensured by paying them to do so' (Wray 2011, 10).

Moreover, this system of measurement only purports to be the profit and loss component of national accounting. The balance sheet is missing, so that the entire inter-generational aspect of government commitments, such as for future unfunded pensions or healthcare, is concealed from the public (Ferguson 2012). Our present measures of economic activity, therefore, are actually doing us harm, and Kelvin's observation must be as valid in social as well as 'hard' science.

\section{Minsky's hypothesis}

Lobbying first undermined Glass-Steagall and eventually got it repealed, in the context of developments which led Minsky to formulate his Financial Instability Hypothesis, published in 1982. He had begun this as an aspect of work on Fisher and debt-deflation, and it culminated in a study of Keynes 'as written about' rather than the Keynes of the textbooks. In this hypothesis, he distinguishes phases of economic growth, starting with the psychological effect of the results of credit invested for genuinely productive enterprises, which can pay interest on the capital advanced and also repay this capital. The success of such enterprises generates optimism about future prospects for the economy generally, so that money comes to be sought for projects which would have been considered too risky in the earlier stage, but to finance which bankers are now willing to 'create money from nothing.' Minsky calls this the 'euphoric' phase of an economic cycle, during which interest may be able to be paid, but there is no ability to repay capital. Finally, in what he designated the 'Ponzi' phase after a notorious swindler of the public, money is lent and borrowed almost completely in anticipation of increasing asset values. When eventually these fail to materialise, the cycle ends in a sudden and massive downturn into recession or depression.

These phases had been evident in the Great Crash and the lead-up to it, and in his 1982 book, Minsky was asking 'Could 'It" Happen Again?' Since it seemed to him 
that it could, why had it not happened up to the time he was writing? Two answers suggest themselves immediately, the first of which is the extent of opportunities for Schumpeterian economic innovation made possible by the US wartime investment in R\&D discussed by Kash; secondly, for as long as the Glass-Steagall Act was in force, US bankers were under effective legal discipline for the first time in their history.

A third reason is the level of debt compared to GDP, which is an index of the relative power of bankers in society. By the time Minsky was writing in 1982 this had yet to reach the levels of the 1920 s, which was the last time financial capital had completely dominated the psyche of the United States - though it was definitely headed in that direction. In the 1920s, the aggregate private debt to GDP ratio had been in the range of $140 \%$ to $175 \%$ of GDP; by 1982, it had reached about $125 \%$. Minsky also identified 1966 as the year when the USA passed from being a financially robust economy to a financially fragile one:

A close examination of experience since World War II shows that the era quite naturally falls into two parts. The first part, which ran for almost twenty years (1948-1966), was an era of largely tranquil progress. This was followed by an era of increasing turbulence, which has continued until today (Minsky 1982, xii).

By 1966, the private debt to GDP ratio had reached $95 \%$ of GDP, from the postWorld war II low of $45 \%$. The trend of increasing debt to GDP, reflecting the increasing economic and political power of bankers, ran from 1945 right through to 2009. On the question of the power of bankers to 'dominate the psyche of the United States,' it is worth noting that shares in the Bank of the United States (from 1791) and the Chartered banks in the individual States for which it was the model, all had limited liability for their owners (McCraw 2012, 131). Also, the penalty for failure for shareholders in banks without a Charter (loss of only twice their investment) was not an effective deterrent to excessive 'creation of money from nothing.'

We can conclude from Minsky's work that the psychology of investors makes booms and busts inevitable, even when finance is being used to bring about generation of real wealth. He was writing of course, before the final, 'Ponzi' stage of the later boom, in which asset values were so largely financial instead.

\subsection{The 'dot-com boom'}

Minsky was Schumpeter's graduate student in Harvard, and another scholar in Schumpeter's tradition, Carlotta Perez, has made a special study of the 'dot-com' boom. She sees both technological and financial cycles as passing through successive stages of installation, deployment and maturity (which includes exhaustion). The last stage in every case is a 'mania' or 'bubble' (Minsky's 'Ponzi' stage) when investors set rationality aside because of obsession with the large profits made during the deployment stage. The dot-com cycle was the last technological one, and Perez notes that because of the amount of financial innovation taking place at the same time, credit was so readily available that it absorbed the slump which would have 
been expected to follow the collapse in value of shares in information technology firms. As she put it,

[T] he aftermath of the NASDAQ bust was not a reckoning and a recomposition of the game board, but a revival of the casino with even greater confidence, this time without the experimental role ... The stock market was indeed no longer centred on the new technologies [whose shares] remained flat while financial stocks grew rapidly in value (Perez 2007, 780, 789, emphasis added).

What this means, Perez claims, is that 'the financial economy has become decoupled from the real economy.' (Perez 2009, 783). Schumpeter's 'Ephors' had finally abandoned any concern with guiding the innovation they financed in the light of the public good. This had been replaced by interests in shaping the laws of property, and capitalism as he understood it was finished.

Identification of one of the roots of this failure can also be traced back to Keynes. As early as in his General Theory in 1936, he was questioning how well financial institutions were performing their task of allocating resources in productive directions. In the famous passage in which he described financial services as a 'casino,' he wrote that poor direction of investment 'is not surprising if I am right in thinking that the best brains of Wall Street have been directed towards a different object' (Keynes $1936,159)$. What would he have said about the financial sector when not only was it gaining more than two-fifths of all corporate profits but allocating resources so badly that Governments have had to become involved in massive bail-outs of banks?

\section{Capitalism's life cycle}

What the foregoing discussion adds up to is that the history of capitalism is intelligible as a process of living off the intellectual capital of the Enlightenment, as expressed in Adam Smith's Theory of Moral Sentiments. The theme of this is altruism, that

However selfish soever man may be supposed, there are evidently some principles in his nature that interest him in the fortunes of others, and render their happiness necessary to him, though he derive nothing from it except the pleasure of seeing it' (Smith [1769-1790] 2002, 11).

This is caused by sympathy, imagination and conscience, which Smith calls 'the supposed impartial spectator, the great inmate of the breast, the great judge and arbiter of conduct' (ibid. 309). It is clearly at the opposite pole to self-interest as the basis for human action, the theme of his The Wealth of Nations.

Both of Smith's approaches can be reconciled if altruism is seen as directed towards formulating the laws which govern society, with self-interest as the motivation for acting within those laws. In this context, it is interesting to note the substantial identity between Smith's 'impartial spectator' in the Theory (182) and John Rawls's 'veil of ignorance' which justice requires in choosing the 'original position' (constitution) of a society (Rawls 1971). That is, those choosing should not know where 
they themselves would be positioned under whatever basic rules are decided upon. We can be altruistic at least to some degree about the formulation of these rules because of our awareness of the enormous value there is for ourselves as well as for others from being able to live under laws that come into being through disinterested choice. Our limited store of altruism can even stretch to acceptance of whatever rules there are as long as they appear to be roughly in the public interest. In contrast, the capture of politicians and the laws they make, by private interests, destroys whatever altruistic bonds may hold a society together. Schumpeter was indeed right to hold that 'the State is only a separate, distinguishable social entity' to the extent that 'it opposes individual egoism as a representative of a common purpose' (Schumpeter [1918] 1991, 110).

In his earlier years, Schumpeter hoped that economics could be a science like physics and so prescribed that it could not look outside self-interest in the form of 'methodological individualism' (Schumpeter [1909] 2010, 437). He also believed that economics needed to be more mathematically based (he was a founder of the Econometric Society). It is ironic, therefore, that neoclassical economics, which fulfilled both of his wishes, should have contributed so much to vindicating his forecast of the end of capitalism through being forced to ignore money and debt if its equations are to work (see Keen 2011).

Capitalism can therefore be seen to have begun with a 'Schumpeterian' phase in which Enlightenment values concerning money (including that it is 'different') resulted in laws which constrained bankers effectively. In the shape of unlimited liability, this discipline made their lending generally productive. This was succeeded by the era of 'free banking' in the United States (i.e. banking with minimum legal constraint and no bureaucratic regulation) made worse by the ending in 1914 of such legal discipline as there was. When this led to the stock market bubble and the Great Crash, the Glass-Steagall Act and similar measures were introduced as attempts to prevent repetition.

\subsection{Irreversible developments?}

Schumpeter was careful to stress that he prophesied nothing, and that in forecasting the end of capitalism he was doing no more than 'extrapolating observable tendencies.' However, this has been more than enough. As a way of organizing economic life, capitalism showed itself to be uniquely capable of underwriting innovation and prosperity, but most of human history had to do without it. It had no intrinsic right to survive indefinitely, and release of bankers from the only discipline that they respected, has been the most important single cause of its decline in the Western world.

It is now inconceivable that any elected government in the countries most affected could be sufficiently free of influence from interests even to attempt to make the laws of property 'conform to the principles on which the institution of private property rests.' Doing so would demand the reimposition of individual unlimited liability on those who deal in money, on two grounds: Firstly, that what they do is different from all other business activity, and secondly because civil servants have proved conclusively that they are unable to regulate them. It would also mean divesting 
corporations of their right to be treated as 'natural persons' and requiring the privilege of shareholding in them to be paid for by total transparency regarding their beneficial ownership. The enormously valuable monopolies delivered by registered trade marks would have to be made subject to public interest conditions, and specific market power in the different forms of protection of information also need to be revised drastically (Kingston 2010). Each and every one of these essential steps would be opposed with all their strength by the interests they would affect.

Judge Richard Posner, with all his authority as a founder of the Law and Economics discipline, has recently written pessimistically about the United States, but his comment applies in one degree or another to all Western democracies:

The adjustments that will be needed, if the economy does not outgrow an increasing burden of debt, to maintain our economic position in the world, may be especially painful and difficult because of features in the American political scene that suggest that the country may be becoming in important respects ungovernable. The perfection of interest-group politics seems to have brought about a situation in which, to exaggerate just a bit, taxes can't be increased, spending programs can't be cut, and new spending is irresistible ...these tendencies are bipartisan (Posner 2010, 371, emphasis added).

Posner is here describing the results of the process of 'hollowing out' democratic governance through its capture by interests, which Schumpeter already sensed was happening when he wrote about 'The Crisis of the Tax State' as long ago as 1918. Only a remarkable optimist could see any economy 'outgrowing an increasing burden of debt' against such a background.

\subsection{Dangers from inequality}

Governance of the European Union has additional problems, largely due to the badly-designed Eurozone, which allowed so much 'Ponzi' banking in some of its member-countries as to leave them insolvent. The final steps to collectivism may not even be peaceful for all of these. This is because of a combination of shallow roots for their democracies and the gross levels of economic inequality to which the capture of legislation by interests has led. In 2011 the OECD produced a study of the development of economic inequality in its member countries, which showed that from 1979 the very top earners (only half of one percent of the total) gained most of what all the others lost. Figures for the US alone indicate that between the final repeal of the Glass-Steagall Act in 1979, and 2007, the richest one per cent of the population received three-fifths of all the huge income gains reflected in Philippon and Reschefs' data. Most of these gains, indeed, went to the richest tenth of that one per cent, and the main cause of this enormously increased inequality has been growth in the financial sector. Since the system which led to this is still thought of as capitalism, such differences must fuel what Schumpeter described as an 'atmosphere of universal hostility to its own social order.' This is one of the main themes in Stiglitz (2012). 
It seems that human beings will accept (and, paradoxically, even value) almost any level of inequality as long as those who are advantaged are seen to perform some necessary social activity, but not otherwise. Indeed, this can be regarded as an aspect of the altruism in respect of the structure of society discussed by Adam Smith in his Theory of Moral Sentiments. de Tocqueville ([1866] 2011) showed that the French revolution only happened after the nobles had been deprived of their powers and functions in local areas, and brought to live parasitic lives at the Court in Paris. The peoples of Russia put up with appalling deprivations for centuries until serfdom was abolished in 1861. After this, the nobles had no social functions to perform and events began to move inexorably to the Bolshevik revolution of 1917 (Pipes 1999). Since the financiers who are the main beneficiaries of the recent explosive growth in economic inequality are not seen as having any legitimate social function, the explosion of world-wide hostility to them and to the policies which made them so rich, could presage worse to come.

Devaluation is not an option for members of the Eurozone, so internal deflation is being imposed upon its poorer countries by austerity measures. The evident failure of these makes it impossible not to be reminded of Keynes's question after he had resigned from the British delegation to the Versailles Peace Treaty over the sanctions being imposed on the defeated countries: 'But who can say how much is endurable, or in what direction men will seek at last to escape from their misfortunes?' (Keynes 1919, 235). Public order in some of these countries may require a return to the military rule they have known in the past, whilst others may experience their own versions of what happened to Germany's Weimar Republic.

\section{Conclusion}

In the second part of Capitalism, Socialism and Democracy, Schumpeter asked the question 'Can Socialism work?' and then answered 'Of course it can!' (Schumpeter [1942] 1997, 169). He then goes on to assert that 'there is nothing wrong with the pure logic of socialism' (ibid. 172). But wherever socialism has been practised, what it has proved it cannot do is provide the conditions for innovation over the widest possible range of technology and consequently for generating wealth on a massive scale. This, as Marx recognised, was capitalism's gift. Only appropriate laws, not intervention, can set self-interest free to be creative and at the same time force it to serve the public good. If we do not get the laws right, intervention cannot work, but to whatever extent we can get them right, intervention becomes unnecessary.

After the fall of the Berlin wall, Keynes's biographer, Robert Skidelsky, described the collectivist polities on the Eastern side of it as having been based on 'belief in the superior wisdom of the State.' This, he added, 'breeds pathologies which deform, and at the limit destroy, the political economies based on it' (Skidelsky 1995, xiii). Growth in this belief in Western countries has been an evident part of the process of 'inevitable decomposition of capitalist society' that Schumpeter foretold. Nowhere is this more clearly visible than in the vain hope that bureaucrats could discipline bankers. 
In the financial crisis, a theoretical option was to allow the banks which had caused it, to fail and be replaced by new banks whose investors would accept unlimited liability. These could only make money by financing Schumpeterian innovation and production, instead of speculation. The fact that taking this option was unthinkable for States (and for the European Union) implicitly recognized that the era of capitalism was finally over for them. Banking in future would be an activity of Governments, even though they would do all they could to pretend that it was 'off their books.' Their decisions finally proved Schumpeter right, both in his sense that modem democratic States would fail 'to oppose individual egoism,' and in his forecast that capitalism would be replaced by socialism.

Acknowledgments I am grateful to an anonymous reviewer for providing a third 'reason' for my discussion of Minsky's Financial Instability Hypothesis.

\section{References}

Appleyard R (1933) The life of Charles Parsons. Constable, London

Arena R, Dangel-Hagnauer C (2002) The contribution of Joseph Schumpeter to economics: economic development and institutional change. Routledge, London

Bessen J, Meurer MJ (2008) Patent failure: how judges, bureaucrats and lawyers put innovators at risk. Princeton University Press, Princeton

Bezemer D (2009) 'No-one saw this coming': understanding financial crisis through accounting models. University of Groningen, Netherlands

Buchanan JM, Tullock G (1962) The calculus of consent. University of Michigan Press, Ann Arbor

Cannan E (1913) Review of NG Pierson: principles of economics. Econ Rev 23:331-333

de Tocqueville A ([1866] 2011) The Ancien Regime and the French revolution. Cambridge University Press, Cambridge

Diamond L, Plattner MF (eds) (1993) Capitalism, socialism and democracy revisited. Johns Hopkins University Press, Baltimore

Ferguson N (2008) The ascent of money: a financial history of the world. Penguin Books, London

Ferguson N (2011) Civilization. Allan Lane, London

Ferguson N (2012) Reith lectures. British Broadcasting Corporation, London

Frydman R, Goldberg MD (2011) Beyond mechanical markets: asset price swings, risk and the role of the state. Princeton University Press, Princeton

Goetzmann WN, Rouwenhorst KG (eds) (2005) The origins of value: the financial innovations that created modem capital markets. Oxford University Press, Oxford

Griffith-Jones S, Ocampo JA, Stiglitz JE (eds) (2010) Time for a visible hand: lessons from the 2008 World Financial Crisis. Oxford University Press, New York

Heggen A (1975) Erfindungschuts und industrialisierung in Preussen, 1793-1877. Vandenhoeck und Ruprecht, Goettingen

Kash DE (1989) Perpetual innovation. Basic Books, New York

Keen S (2011) Debunking economics: the naked emperor dethroned? Zed Books, London

Keen S (2012) Transcript of BBC interview with Paul Mason, 10 June. British Broadcasting Corporation, London

Keynes JM (1919) The economic consequences of the peace. Macmillan, London

Keynes JM (1930) A treatise on money. Macmillan, London

Keynes JM (1936) The general theory of employment, interest and money. Macmillan, London

Kingston W (2004) Light on simultaneous invention from US Patent Office "Interference" records. World Patent Inf 26:209-220

Kingston W (2006) Schumpeter, business cycles and co-evolution. Ind Innov 13(1):97-106 
Kingston W (2010) Beyond intellectual property: matching information protection to innovation. Edward Elgar, Cheltenham

Kingston W, Scally K (2006) Patents and the measurement of international competitiveness. Edward Elgar, Cheltenham

Lazonick W (2009) Sustainable prosperity in the new economy: business organization and hightech employment in the United States. WE Upjohn Institute for Employment Research, Kalamazoo

Marx K ([1889] 1995) In: McClellan D (ed) Capital. Oxford University Press, Oxford

Marx K, Engels F ([1849] 1967) The communist manifesto. Penguin Books, London

McCloskey D (2006) The bourgeois virtues: ethics in an age of commerce. University of Chicago Press, Chicago

McCloskey D (2010) Bourgeois dignity: why economics can't explain the modem world. University of Chicago Press, Chicago

McCraw TK (2012) The founders and finance. The Belknap Press of Harvard University Press, Cambridge

McLeod HD (1889) The theory of credit. Longmans, London

Mill JS ([1848] 2004) Principles of political economy. John Murray, London

Minsky HP (1982) Can "It" happen again? Essays on instability and finance. ME Sharpe, Armonk

Monypenny WF, Buckle AL (1910) Life of Benjamin Disraeli, Earl of Beaconsfield. John Murray, London

North DC, Wallis IJ, Weingast BR (2009) Violence and social orders. Cambridge University Press, Cambridge

Nowotny E (2004) Evolution of structures of European economic policy. J Evol Econ 14(2):211-215

OECD (2011) Divided we stand; why inequality keeps rising, e-book, published 05 December

Olson M (1982) The rise and decline of nations. Yale University Press, New Haven

Perez C (2007) Finance and technical change: a long-term view. In: Elgar companion to NeoSchumpeterian economics. Edward Elgar, Cheltenham

Perez C (2009) The double bubble at the turn of the century: technological roots and structural implications. Camb J Econ 33(4):779-805

Perino M (2010) The hellhound of wall street: how Ferdinand Pecora's investigation of the great crash forever changed American Finance. Penguin Press, New York

Philippon T, Reschef A (2009) Wages and human capital in the US financial industry: 1909-2006. National Bureau of Economic Research Working Paper No 14644

Pipes R (1999) Property and freedom. Harvill Press, London

Posner R (2010) The crisis of capitalist democracy. Harvard University Press, Cambridge

Rawls J (1971) A theory of justice. Belknap Press, Cambridge

Ripert G (1946) Aspects juridiques du capitalisme modeme. Hachette, Paris

Schumpeter JA ([1909] 2010) The nature and essence of economic theory English translation by McDaniel, BA. Transaction Publishers, New Brunswick

Schumpeter JA ([1911] 1934) The theory of economic development, English translation by Opie R. Harvard University Press, Cambridge

Schumpeter JA ([1918] 1991) The crisis of the tax state. English translation. In: Swedberg R (ed) The economics and sociology of capitalism / Joseph A Schumpeter. Princeton University Press, Princeton

Schumpeter JA (1939) Business cycles. McGraw-Hill, New York

Schumpeter JA (1942) Capitalism, socialism and democracy. Allen and Unwin, London

Schumpeter JA (1949) The communist manifesto in sociology and economics. J Polit Econ 57(3):199-212

Sheppard DK (2006) The growth and role of UK financial institutions, 1880-1962. Routledge, London

Skidelsky R (1995) The world after communism. Macmillan, London

Smith A ([1769-1790] 2002) In: Haalconssen K (ed) The theory of moral sentiments. Cambridge University Press, Cambridge

Smith A ([1776] 1976) In: Cannan E (ed) An enquiry into the nature and causes of the wealth of nations. Chicago University Press, Chicago

Stigler G (1971) The theory of economic regulation. Bell J Econ 2:3-21

Stiglitz J (2012) The price of inequality. Allan Lane, London

Stiglitz J, Sen A, Fitoussi J-P (2009) Report by the commission on the measurement of economic performance and social progress. Available at: www.stiglitz-sen-fitoussi.fr. Accessed 5 February 2013

Turner JD (1988) The introduction of limited liability and the resulting growth of comprehensive bank regulation. Queen's University, Belfast, Dissertation

Usher D (1981) The economic prerequisite to democracy. Blackwell, Oxford

Weber M ([1921] 1978) Economy and society. University of California Press, Berkeley 
Whalen C (2011) Inflated: how money and debt built the American dream. Wiley, Hoboken White L Jr (1964) Medieval technology and social change. Oxford University Press, Oxford

Wray LR (2009) The rise and fall of money manager capitalism: a Minskian approach. Camb J Econ 33(4):807-828

Wray LR (2011) Minsky's money manager capitalism and the global financial crisis. Int J Polit Econ 40(2):5-20 